\title{
Faktor-Faktor Yang Berhubungan Dengan Kejadian Filariasis Di Kecamatan Buaran Kabupaten Pekalongan
}

\author{
Suryo Sularno ${ }^{1}$, Nurjazuli², Mursid Raharjo ${ }^{2}$ \\ ${ }^{1}$ Badan Penanggulangan Bencana Daerah (BPBD) Jawa Tengah \\ ${ }^{2}$ Fakultas Kesehatan Masyarakat Universitas Diponegoro
}

Info Artikel : Diterima Januari 2017 ; Disetujui Maret 2017 ; Publikasi April 2017

\begin{abstract}
ABSTRAK
Latar belakang: Filariasis merupakan salah satu penyakit infeksi, disebabkan oleh cacing filaria yang hidup di kelenjar limfa dan darah manusia, termasuk penyakit tular vektor. Kecamatan Buaran Kabupaten Pekalongan merupakan daerah endemis filariasis tinggi dengan mf rate 3,9\%, Selain itu, hasil survei darah jari yang pernah dilakukan, di wilayah ini ditemukan 37 orang positif mikrofilaria dalam darahnya. Penelitian ini bertujuan untuk menggambarkan faktor lingkungan dan perilaku masyarakat sebagai faktor risiko kejadian filariasis di Kecamatan Buaran kabupaten Pekalongan.

Metode: Penelitian ini menggunakan disain kasus kontrol. Subyek penelitian dibagi menjadi kelompok kasus dan kelompok kontrol masing-masing 74 orang. Variabel bebas yang dikaji dalam penelitian ini adalah spesies keberadaan nyamuk di dalam dan luar rumah, kawat kasa, persawahan, saluran air, genangan air, tumbuhan air, dan ternak. Faktor perilaku meliputi kebiasaan penggunaan kelambu, menggantung pakaian, penggunaan obat anti nyamuk, keluar ada malam hari, pengetahuan dan layanan kesehatan. Variabel terikatnya adalah kejadian filariasis. Pengumpulan data dilakukan dengan wawancara, observasi, dan penangkapan nyamuk. Analisis data hasil penelitian menggunakan regresi logistik.

Hasil: Dari 17 variabel bebas yang dikaji, hasil penelitian ini menemukan ada tiga variabel yang mempunyai asosiasi signifikan dengan kejadian filatiasis di Kecamatan Buaran Kabupaten Pekalongan. Variabel tersebut meliputi tinggal di sekitar rumah penderita, kepadatan hunian, dan kepatuhan minum obat. Hasil analisis regresi logistik menunjukkan bahwa kepadatan hunian merupakan faktor yang paling dominan pengaruhnya terhadap kejadian filariasis dengan $\mathrm{OR}=6,145$ (CI:1,051 - 35,938).

Simpulan: Penelitian ini menyimpulkan bahwa tinggal di sekitar rumah penderita, kepadatan hunian dan kepatuhan minum obat filariais mempunyai kontribusi terhadap kejadian filariasis. Peneliti menyarankan upaya perbaikan lingkungan yang sehat dan kepatuhan minum obat oleh masyarakat perlu diupayakan semaksimal mungkin guna menekan kejadian penyakit tersebut di masa mendatang.
\end{abstract}

Kata kunci: Faktor lingkungan dan perilaku; filariasis; Buaran Pekalongan.

\section{ABSTRACT}

Title: Factors Related toThe Incidence of Lymphatic Fillariasis in Buaran, Pekalongan District

Background: Filariasis or elephansiasis is one of infectious disease, is a systemic infection caused by filarial worms that live in the lymph nodes (lymph) and human blood that transmitted by mosquitoes (vector-borne disease). The survey result endemicity of filariasis in 2007 found that the highest area was in Buaran District with the number of microfilariae $(\mathrm{mf})$ rate of 3.9\% and according to the data Filariasis Research 2015, the result of Finger-prick Blood in Subdistrict Buaran discovery of microfilariae are 37 people. Based on this fact the purpose of this research is to 
describe environmental condition and behaviour society as a risk factor for the incidence of filariasis in Subdistrict Buaran Pekalongan regency.

Method: This study was observational study with case control design. The subjects consisted of two groups of case and control, with each sample of 74 people. The independent variables studied were the vectors inside and outside the home existing, marshes existing, rice fields existing, trenches existing, ditches, puddles, aquatic plants existing, bushes existing, cattle existing, wire netting on the ventilation esiting, the habit of using nets, habits of hanging clothes have been used, the habit of using anti-mosquito drugs, the habit outdoors at night, knowledge and health efforts. While the dependent variable was the incidence of filariasis. Data was collected through interviews, observation, and measurement. Data would be analyzed using univariate, bivariate chi-square, and multivariate logistic regression at level of significance $0.05(5 \%)$.

Result: Bivariate analyze of 17 variables are the vectors inside and outside the home existing, marshes existing, rice fields existing, trenches existing, ditches, puddles, aquatic plants existing, bushes existing, cattle existing, wire netting on the ventilation esiting, the habit of using nets, habits of hanging clothes have been used, the habit of using antimosquito drugs, the habit outdoors at night, knowledge and health efforts, indicated that there were three variables that have a correlation to incidence of filariasis. They were staying or being around filariasis sufferers, density residential, and medication adherence. Results of multivariate analysis that density residential is the most dominant factor related to the incidence of filariasis with $p$-value $=0.044 ; O R=6,145(1,051-35,938)$.

Conclusion: This study concluded that environment factors need to be improved, especially for staying or being around filariasis sufferers, density residential, and medication adherence to reduce fillariasis incident.

Keyword: Environment and behaviour factors; Filariasis;Buaran Pekalongan.

\section{PENDAHULUAN}

Penyebaran penyakit di negara berkembang saat ini mengalami perubahan, namun penyakit menular masih berperan sebagai penyebab utama kesakitan, kecacatan bahkan kematian. Filariasis atau penyakit kaki gajah merupakan salah satu penyakit menular, adalah suatu infeksi sistemik yang disebabkan cacing filaria yang hidup dalam kelenjar getah bening (limfa) dan darah manusia yang ditularkan melalui gigitan nyamuk (vector borne disease). Penyakit ini tidak mengakibatkan kematian, tetapi dapat mengakibatkan kecacatan seumur hidup. Kecatacatan berupa pembesaran kaki, lengan dan alat kelamin baik perempuan maupun laki-laki, sehingga menimbulkan stigma sosial, hambatan psikososial serta menurunkan produktivitas kerja penderita, keluarga, dan masyarakat yang menimbulkan kerugian ekonomi yang besar.

Terdapat 1,1 miliar penduduk yang tertular filariasis terutama di daerah tropis dan beberapa subtropics (lebih dari 83 negara) Sedangkan di Indonesia sampai dengan tahun 2004 diperkirakan 6 juta orang terinfeksi filariasis dan dilaporkan lebih dari 8.243 diantaranya menderita klinis filariasis kronis. ${ }^{1}$ Kabupaten Pekalongan termasuk salah satu daerah endemis filariasis. Hasil survei endemisitas filariasis oleh Dinas Kesehatan Kabupaten Pekalongan pada tahun 2007 menunjukkan hasil tertinggi terdapat di Kecamatan Buaran dengan angka mikrofilaria $(m f)$ rate 3,9\%. Hasil Survey Darah Jari (SDJ) pada tahun 2015di Kecamatan Buaran ditemukan mikrofilaria adalah sebanyak 37 orang. $^{2}$

Faktor lingkungan merupakan salah satu pencetus timbulnya kejadian filariasis. Lingkungan biologik (keberadaan tanaman air, keberadaan ikan predator, keberadaan semak-semak dan keberadaan ternak) dan lingkungan fisik (genangan air, keberadaan kolam, keberadaan parit, keberadaan air sawah dan rawa) yang sesuai dengan vector tertentu akan meningkatkan kepadatan vector filariasis. Nyamuk sebagai vektor filaria yang ada di Indonesia telah diketahui terdapat 23 spesies dari genus Mansonia, Anopheles, Culex, Aedes dan Armigere. ${ }^{3}$ Nyamuk Cx. Quinquefasciatus. Nyamuk tersebut mempunyai habitat pada saluran air yang tercemar bahan organik. Larva $C x$. Quinquefasciatus banyak dijumpai di air tercemar, saluran air,selokan dan genangan air yang berhubungan langsung dengan tanah. ${ }^{4}$

Penelitian di Kabupaten Pekalongan membuktikan bahwa keberadaan genangan air menjadi faktor risiko filariasis dan keberadaan rawa merupakan faktor risiko terbesar kejadian filariasis di Kabupaten Pekalongan dan kebiasaan berada di luar rumah pada waktu malam hari, penggunaan obat nyamuk dan penggunaan kain kasa juga berpengaruh terhadap kejadian filariasis.

Kecamatan Buaran yang termasuk daerah beriklim tropis dengan curah hujan yang sedang, suhu udara antara suhu $27^{\circ} \mathrm{C}-30^{\circ} \mathrm{C}$. Wilayah ini merupakan daratan dan sebagian terdiri dari sawah dan rawa. Banyaknya genangan air limbah rumah tangga maupun limbah yang berasal dari pabrik dan masih banyaknya semak-semak di sekitar rumah menjadi tempat perindukan yang baik bagi nyamuk vektor filariasis. Berdasarkan latar belakang tersebut, maka penelitian ini bertujuan untuk mengetahui gambaran kondisi lingkungan dan perilaku masyarakat sebagai yang berhubungan dengan kejadian filariasis di Kecamatan Buaran Kabupaten Pekalongan. 


\section{MATERI DAN METODE}

Penelitian ini merupakan penelitian observasional analitik dengan rancangan case control (kasus kontrol) yaitu menelaah hubungan antara efek (penyakit atau kondisi kesehatan) tertentu dengan faktor risiko tertentu. Populasi dalam penelitian ini adalah semua orang di wilayah Kecamatan Buaran yang pernah diperiksa sediaan darahnya pada Survei Darah jari (SDJ). Sampel kelompok kasus yaitu orang di wilayah Kecamatan Buaran yang pernah diperiksa sediaan darahnya pada SDJ dan dinyatakan positif mikrofilaria berdasarkan hasil survei sampai 2015. Sample kelompok kontrol adalah orang tinggal di wilayah kecamatan yang sama dengan kasus dan pernah diperiksa sediaan darahnya tetapi hasilnya negatif mikrofilaria.

Adapun pengambilan sample pada kelompok kasus diambil dari seluruh populasi, sedangkan untuk kelompok kasus diambil dengan purposive sampling dengan pertimbangan mereka yang tinggal di wilayah kecamatan yang sama dan tidak tinggal serumah dengan kasus.

Analisa data dilakukan secara univariat, bivariat, dan multivariat. Analisa data univariat dilakukan untuk variabel yang diteliti meliputi keberadaan vektor di dalam dan di luar rumah, keberadaan rawa-rawa, keberadaan sawah, keberadaan parit, selokan, genangan air, keberadaan tumbuhan air, keberadaan semak-semak, keberadaan ternak, keberadaan kawat kasa pada ventilasi, kepadatan unian, tinggal di sekitar penderita, kebiasaan menggunakan kelambu, kebiasaan menggantung baju yang sudah dipakai, kebiasaan menggunakan obat anti nyamuk, kebiasaan di luar rumah pada malam hari, pengetahuan dan upaya kesehatan. Analisis data secara bivariat dengan Chi-square dan analisis multivariat menggunakan regresi logistik.

\section{HASIL DAN PEMBAHASAN}

Penelitian dilakukan di Kecamatan Buaran Kabupaten Pekalongan dengan luas wilayah 9,54 km². Subyek penelitian terdiri dari 37 kasus dan 37 kontrol. Kasus filariasis di lokasi penelitian diderita oleh masyarakat yang berumur 20 sampai 80 tahun dengan rerata 44,92 tahun. Karakterisrik subyek penelitian dapat dilihat pada tabel 1 .

Tabel 1. Karakteristik subyek penelitian

\begin{tabular}{lcc}
\hline Karakteristik & $\begin{array}{c}\text { Kasus } \\
\mathbf{n = 3 7}\end{array}$ & $\begin{array}{c}\text { Kontrol } \\
\mathbf{n = 3 7}\end{array}$ \\
\hline Tingkat pendidikan: & & \\
Tidak tamat SD & $3(8,1 \%)$ & $0(0 \%)$ \\
Tamat SD & $16(43,2 \%)$ & $11(29,7 \%)$ \\
Tamat SMP & $13(35,1 \%)$ & $11(29,7 \%)$ \\
Tamat SMA & $4(10,8 \%)$ & $14(37,8 \%)$ \\
Tamat Sarjana & $1(2,7 \%)$ & $1(2,7 \%)$ \\
\hline Pekerjaan: & & \\
Nelayan & $5(13,5 \%)$ & $10(27,0 \%)$ \\
\hline
\end{tabular}

\begin{tabular}{lcc}
\hline Petani & $1(2,7 \%)$ & $0(0,0 \%$ \\
Buruh pabrik & $3(8,1 \%)$ & $14(37,8 \%)$ \\
Karyawan & $5(13,5 \%)$ & $1(2,7 \%)$ \\
Wiraswasta & $23(62,2 \%)$ & $11(29,7 \%)$ \\
Buruh tani & $0(0,0 \%)$ & $1(2,7 \%)$ \\
\hline
\end{tabular}

Tingkat pendidikan pada kelompok kasus paling banyak adalah tamat SD (43,2 \%). Sedangkan pada kelompok kontrol paling banyak adalah tamat SMA $(37,8 \%)$. Pendidikan responden paling sedikit menduduki tingkat yang sama antara kelompok kasus dan kelompok control (2,7\%). Jenis pekerjaan pada kelompok kasus, paling banyak adalah wiraswasta $(62,2$ $\%)$. Sedangkan pada kelompok kontrol adalah buruh pabrik $(37,8 \%)$ dan pekerjaan responden paling sedikit menduduki tingkat yang sama antara kelompok kasus dan kelompok control $(2,7 \%)$.

\section{Karakteristik Lingkungan}

Kabupaten Pekalongan mempunyai suhu dengan kisaran $24^{0}-30^{\circ} \mathrm{C}$, demikian pula untuk Kecamatan Buaran. Dalam penelitian ini hanya dilakukan Survey Resting Collecting nyamuk dewasa pada pagi hari di 2 desa yaitu di Desa Wonoyoso dan Desa Simbang Kulon di peroleh hasil kelembaban sebesar $78-85 \%$ dan suhu $27^{\circ} \mathrm{C} \quad-30^{\circ} \mathrm{C}$. Kelembaban yang optimal untuk perkembangbiakan nyamuk di atas $80 \%$, sehingga kelembaban di Kecamatan Buaran merupakan kelembaban yang ideal bagi nyamuk. Begitu pula dengan suhu di Kecamatan Buaran merupakan suhu yang ideal bagi perkembangbiakan nyamuk.

Berdasarkan tabel 2, nyamuk yang ditangkap di Desa Wonoyoso, 55\% nyamuk dalam kondisi penuh darah diperutnya. Demikian juga dengan yang ditangkap di Desa Simbang Kulon, 96\% nyamuk kondisinya juga perutnya penuh darah. Adapun spesies yang tertangkap adalah Culex quinquefasciatus, Aedes aegypti, dan Culex fatigas. Namun dari hasil penangkapan ini menemukan bahwa spesias terbanyak adalah Culex quinquefasciatus $(90,7 \%)$. Tentunya ini menjadi salah satu faktor terjadinya penularan filariasis di wilayah Kecamatan Buaran. Hasil penangkapan nyamuk pada penelitian ini menunjukan variasi spesies yang hampir sama dengan penelitian lain yang pernah dilakukan sebelumnya di wilayah Pekaloangan. Hasil penelitian Ike di Kecamatan Pekalongan Selatan menemukan tiga spesies nyamuk yaitu Culex quinquefasciatus, Culex vishnui, dan Aedes aegypti dan proporsi terbesar adalah Culex quinquefasciatus $(71 \%)$ dengan infection rate sebesar $6,6 \%{ }^{5}$ Penelitian lain yang dilakukan oleh Nurjazuli juga menunjukkan pola yang hampir sama. Tiga sepesies ditemukan di wilayah Pekalongan ini adalah Culex quinquefasciatus, Aedes aegypti, dan Armigeres sulbabatus. Sebagian besar nyamuk yang tertangkap dan dilakukan pembedahan didominasi spesies Culex quinquefasciatus $(90,88 \%)$ dengan infection rate $16,3 \%$. 
Penelitian Nurjazuli di Kota Pekalongan ini juga cacing/ekor nyamuk dan beban cacing tertinggi 12 menunjukkan rerata beban cacing L3 adalah 4,9 cacing/ekor nyamuk. $^{6}$

Tabel 2. Hasil penangkapan nyamuk di Kecamatan Buaran Kabupaten Pekalongan 2016

\begin{tabular}{|c|c|c|c|c|c|c|c|c|c|}
\hline \multirow{3}{*}{ No. } & \multirow{3}{*}{ Spesies } & \multicolumn{6}{|c|}{ Lokasi } & \multirow{2}{*}{\multicolumn{2}{|c|}{ Jumlah }} \\
\hline & & \multicolumn{2}{|c|}{ Rumah A } & \multicolumn{2}{|c|}{ Rumah B } & \multicolumn{2}{|c|}{ Rumah C } & & \\
\hline & & Feed & Unfeed & Feed & Unfeed & Feed & Unfeed & Feed & Unfeed \\
\hline \multicolumn{10}{|c|}{ Desa Wonoyoso: } \\
\hline 1 & Culex Quinqifasciotus & 14 & 22 & 8 & 18 & 8 & 16 & 30 & 56 \\
\hline 2 & Aedes Aegypti & 0 & 0 & 0 & 0 & 0 & 2 & 0 & 2 \\
\hline \multirow[t]{2}{*}{3} & Culex Fatigans & 2 & 0 & 1 & 1 & 0 & 1 & 3 & 2 \\
\hline & Jumlah & 16 & 22 & 9 & 19 & 8 & 19 & 33 & 60 \\
\hline \multicolumn{10}{|c|}{ Desa Simbang Kulon } \\
\hline 1 & Culex Quinqifasciotus & 2 & 3 & 14 & 21 & 22 & 18 & 38 & 42 \\
\hline \multirow[t]{2}{*}{2} & Aedes Aegypti & 1 & 0 & 4 & 1 & 1 & 3 & 6 & 4 \\
\hline & Jumlah & 3 & 3 & 18 & 22 & 23 & 21 & 44 & 46 \\
\hline
\end{tabular}

\section{Faktor Risiko Kejadian Filariasis}

Tabel 3. Faktor-faktor yang berhubungan dengan kejadian ilariasis di Kecamatan Buaran Kabupaten Pekalongan tahun

\begin{tabular}{|c|c|c|c|c|c|c|}
\hline No & Karakteristik & $\begin{array}{c}\text { Kasus } \\
\mathrm{n}=37\end{array}$ & $\begin{array}{c}\text { Kontrol } \\
n=37\end{array}$ & OR & $95 \% \mathrm{CI}$ & p-value \\
\hline 1 & $\begin{array}{l}\text { Kepadatan hunian } \\
\text { a. Padat } \\
\text { b. Tidak padat }\end{array}$ & $\begin{array}{c}31(83,8 \%) \\
6(16,2 \%)\end{array}$ & $\begin{array}{l}25(67,6 \%) \\
12(32,4 \%)\end{array}$ & 2,480 & $0,815-7,545$ & 0,176 \\
\hline 2 & $\begin{array}{l}\text { Kelambu } \\
\text { a. Tidak (tidak } \\
\text { menggunakan) } \\
\text { b. Ya (menggunakan } \\
\text { kelambu) }\end{array}$ & $\begin{array}{c}36(97,3 \%) \\
1(2,7 \%)\end{array}$ & $\begin{array}{c}36(97,3 \%) \\
1(2,7 \%)\end{array}$ & 1,000 & $0,060-16,611$ & 1,000 \\
\hline 3 & $\begin{array}{l}\text { Obat anti nyamuk } \\
\text { a. Tidak } \\
\text { b. Menggunakan }\end{array}$ & $\begin{array}{c}1(2,7 \%) \\
36(97,3 \%) \\
\end{array}$ & $\begin{array}{c}1(2,7 \%) \\
36(97,3 \%) \\
\end{array}$ & 1,000 & $0,060-16,611$ & 1,000 \\
\hline 4 & $\begin{array}{l}\text { Tinggal di sekitar penderita: } \\
\text { a. Ya } \\
\text { b. Tidak }\end{array}$ & $\begin{array}{c}17(45,9 \%) \\
20(54,1)\end{array}$ & $\begin{array}{c}36(97,3 \%) \\
1(2,7 \%) \\
\end{array}$ & 0,024 & $0,003-0,191$ & 0,000 \\
\hline 5 & $\begin{array}{l}\text { Berada di luar rumah: } \\
\text { a. Ya } \\
\text { b. Tidak }\end{array}$ & $\begin{array}{l}14(37,8 \%) \\
23(62,2 \%)\end{array}$ & $\begin{array}{l}25(67,6 \%) \\
12(32,4 \%)\end{array}$ & 0,292 & $0,112-0,761$ & 0,020 \\
\hline 6 & $\begin{array}{l}\text { Pengetahuan: } \\
\text { a. Tidak tahu } \\
\text { b. Tahu }\end{array}$ & $\begin{array}{l}15(40,5 \%) \\
22(59,5 \%)\end{array}$ & $\begin{array}{l}22(59,5 \%) \\
15(40,5 \%)\end{array}$ & 2,151 & $0,850-5,442$ & 0,163 \\
\hline 7 & $\begin{array}{l}\text { Pengobatan: } \\
\text { a. Tidak } \\
\text { b. Ya }\end{array}$ & $\begin{array}{c}28(75,7 \%) \\
9(24,3 \%)\end{array}$ & $\begin{array}{l}14(37,8 \%) \\
23(62,2 \%)\end{array}$ & 5,111 & $1,875-13,931$ & 0,002 \\
\hline 8 & $\begin{array}{l}\text { Menggantung baju: } \\
\text { a. Ya } \\
\text { b. Tidak }\end{array}$ & $\begin{array}{c}35(94,6 \%) \\
2(5,4 \%)\end{array}$ & $\begin{array}{c}36(97,3 \%) \\
1(2,7 \%)\end{array}$ & 0,486 & $0,042-5,606$ & 1,000 \\
\hline 9 & $\begin{array}{l}\text { Keberadaan kawat kasa } \\
\text { a. Tidak ada } \\
\text { b. Ada }\end{array}$ & $\begin{array}{c}8(21,6 \%) \\
29(78,4 \%)\end{array}$ & $\begin{array}{l}10(27,0 \%) \\
27(73,0 \%)\end{array}$ & 0,745 & $0,256-2,166$ & 0,786 \\
\hline
\end{tabular}




\begin{tabular}{|c|c|c|c|c|c|c|}
\hline 10 & $\begin{array}{l}\text { Keberadaan Parit } \\
\text { a. Tidak ada } \\
\text { b. Ada }\end{array}$ & $\begin{array}{c}10(27,0 \%) \\
27(73,0 \%)\end{array}$ & $\begin{array}{l}13(35,1 \%) \\
24(64,9 \%)\end{array}$ & 0,684 & $0,254-1,842$ & 0,615 \\
\hline 11 & $\begin{array}{l}\text { Keberadaan Selokan } \\
\text { a. Ada } \\
\text { b. Tidak ada }\end{array}$ & $\begin{array}{l}27(73,0 \%) \\
10(27,0 \%)\end{array}$ & $\begin{array}{c}30(81,1 \%) \\
7(18,9 \%)\end{array}$ & 0,630 & $0,210-1,887$ & 0,580 \\
\hline 12 & $\begin{array}{l}\text { Keberadaan genangan air } \\
\text { a. Ada } \\
\text { b. Tidak }\end{array}$ & $\begin{array}{c}33(89,2 \%) \\
4(10,8 \%) \\
\end{array}$ & $\begin{array}{c}34(91,9 \%) \\
3(8,1 \%) \\
\end{array}$ & 0,728 & $0,151-3,505$ & 1,000 \\
\hline 13 & $\begin{array}{l}\text { Keberadaan rawa-rawa } \\
\text { a. Ada } \\
\text { b. Tidak ada }\end{array}$ & $\begin{array}{l}22(59,5 \%) \\
15(40,5 \%) \\
\end{array}$ & $\begin{array}{l}26(70,3 \%) \\
11(29,7 \%)\end{array}$ & 0,728 & $0,151-3,505$ & 1,000 \\
\hline 14 & $\begin{array}{l}\text { Keberadaan Sawah } \\
\text { a. Ada } \\
\text { b. Tidak ada }\end{array}$ & $\begin{array}{c}2(5,4 \%) \\
35(94,6 \%)\end{array}$ & $\begin{array}{c}616,2 \%) \\
31(83,3 \%)\end{array}$ & 0,295 & $0,055-1,571$ & 0,261 \\
\hline 15 & $\begin{array}{l}\text { Keberadaan ternak } \\
\text { a. Ada } \\
\text { b. Tidak ada }\end{array}$ & $\begin{array}{l}24(64,9 \%) \\
13(35,1 \%) \\
\end{array}$ & $\begin{array}{c}31(83,8 \%) \\
6(16,2 \%) \\
\end{array}$ & 0,357 & $0,118-1,078$ & 0,110 \\
\hline 16 & $\begin{array}{l}\text { Keberadaan semak-semak } \\
\text { a. Ada } \\
\text { b. Tidak ada }\end{array}$ & $\begin{array}{l}22(59,5 \%) \\
15(40,5 \%)\end{array}$ & $\begin{array}{l}26(70,3 \%) \\
11(29,7 \%)\end{array}$ & 0,621 & $0,237-1,626$ & 0,465 \\
\hline 17 & $\begin{array}{l}\text { Keberadaan tanaman air } \\
\text { a. Ada } \\
\text { b. Tidak ada }\end{array}$ & $\begin{array}{c}2(5,4 \%) \\
35(94,6 \%)\end{array}$ & $\begin{array}{c}5(13,5 \%) \\
32(86,5 \%)\end{array}$ & 0,366 & $0,066-2,019$ & 0,427 \\
\hline
\end{tabular}

Hasil analisis bivariate pada tabel 3 menunjukkan bahwa responden yang tinggal di rumah dengan kepadatan hunian bukan merupakan faktor risiko terjadinya filariasis. Hal ini ditunjukan dengan $p$-value $=0,176 ; \mathrm{OR}=2,480$ dan $95 \% \quad \mathrm{CI}=0,815-7,545$. Hasil penelitian ini berbeda dengan penelitian Syuhada Yudi ${ }^{7}$, yang menyatakan kepadatan hunian merupakan faktor risiko terjadinya filariasis, dengan $p$-value $=0,003 ; \mathrm{OR}=$ 3,364 dan $95 \% \mathrm{CI}=1,490-7,591$. Rumah dengan kepadatan hunian yang tinggi akan mendatangkan nyamuk yang lebih banyak. Hal ini bisa disebakan oleh karena kelembaban akan menjadi tinggi dan disukai nyamuk.

Penggunaan kelambu terbukti bukan sebagai faktor risiko terjadinya filariasis. Hal ini ditunjukan dengan $p$ value $=1,000 . \mathrm{OR}=1,000$ dan $95 \% \mathrm{CI}=0,060-16,611$. Hasil penelitian ini sejalan dengan penelitian yang dilakukan oleh Puji Juriastuti yang mengatakan bahwa kebiasaan tidur tidak berkelambu tidak ada hubungannya dengan kejadian filariasis, dengan nilai $(\mathrm{OR}=2,348$; $p$ value $=0,246){ }^{8}$ Berdasarkan penelitian para ahli, mengatakan bahwa penggunaan kelambu sewaktu tidur merupakan cara utama untuk kita menghindari dari gigitan nyamuk dan mengendalikan agar nyamuk tersebut tidak menularkan penyakit seperti filariasis, malaria, DBD. ${ }^{9}$ Akan tetapi juga dipengaruhi oleh kondisi fisik kelambu itu sendiri
Penggunaan obat anti nyamuk bukan merupakan faktor risiko terjadinya filariasis karena $p$-value $=$ 1,$000 ; \mathrm{OR}=1,000$ dan $95 \% \mathrm{CI}=0,060-16,611$. Hal ini tidak sejalan dengan penelitian yang dilakukan oleh Febriyanto yang mengatakan bahwa responden yang tidak menggunakan obat anti nyamuk berisiko terkena filariasis sebesar 6,32 kali dibandingkan dengan responden yang menggunakan obat anti nyamuk, dan hubungannya bermakna $(p$-value $=0,03) .8$ Metode perlindungan diri dengan menggunkan obat anti nyamuk digunakan oleh individu atau kelompok masyarakat untuk melindungi diri dari gigitan nyamuk dengan cara mencegah kontak antara tubuh manusia dengan nyamuk, dimana peralatannya kecil, mudah dibawa dan sederhana dalam penggunaannya, diantaranya obat anti nyamuk seperti: bakar, koil dan obat poles anti nyamuk. ${ }^{10}$

Pengetahuan tentang filariasis pada penelitian ini terbukti secara statistik bukan merupakan faktor risiko terjadinya filariasis. Hal ini ditunjukan dengan $p$-value $=$ 0,$163 ; \mathrm{OR}=2,151$ dan $95 \% \mathrm{CI}=0,850-5,442$ ). Kebiasaan menggantung baju pada penelitian ini terbukti secara statistik bukan merupakan faktor risiko terjadinya filariasis karena $p$-value $=1,000 ; \mathrm{OR}=0,486$ dan $95 \% \mathrm{CI}$ $=0,042-5,606$.

Keberadaan kawat kasa pada ventilasi rumah pada penelitian ini terbukti bukan sebagai faktor risiko terjadinya filariasis, karena hasil $p$-value $=0,786$; $\mathrm{OR}=$ 
0,745 dan $95 \% \mathrm{CI}=0,256-2,166$. Hal ini tidak sejalan dengan penelitian yang dilakukan oleh Reyke uloli yang mengatakan bahwa rumah yang ventilasinya tidak menggunakan kawat kasa berisiko 2,078 kali untuk mengalami filariasis dibandingkan dengan yang ventilasinya menggunakan kawat kasa dan hubungannya bermakna. ${ }^{11}$ Pemasangan kawat kasa pada ventilasi akan menyebabkan semakin kecilnya kontak nyamuk yang berada di luar rumah dengan penghuni rumah, dimana nyamuk tidak dapat masuk ke dalam rumah.8

Keberadaan parit di luar rumah pada penelitian ini tidak terbukti sebagai faktor risiko filariasis dengan $p$ value $=0,615 ; \mathrm{OR}=0,684$ dan $95 \% \mathrm{CI}=0,254-1,842$. Hasil penelitian ini sejalan dengan penelitian yang dilakukan oleh Febriyanto, dkk, 2008, yang mengatakan bahwa keberadaan parit di luar rumah tidak ada hubungannya dengan kejadian filariasis, dengan nilai $(\mathrm{OR}=0,49 ;$-value $=0,44) .8$ Keberadaan selokan pada penelitian ini terbukti bukan sebagai faktor risiko terjadinya filariasis, dengan $p$-value $=0,580 . \mathrm{OR}=0,630$ dan $95 \% \mathrm{CI}=0,210-1,887$.

Keberadaan genangan air pada penelitian ini terbukti bukan sebagai faktor risiko terjadinya filariasis, dengan $p$-value $=1,000 ;$ OR adjusted $=0,728$ dan $95 \%$ $\mathrm{CI}=0,151-3,505$. Hal ini sama dengan hasil penelitian yang dilakukan oleh Nasrin (2008), juga terbukti tidak berhubungan dengan kejadian filariasis $(\mathrm{OR}=1,871$; $p$ value $=0,202)$. Genangan air merupakan tempat perindukan nyamuk Culex quinquefasciatus yang paling disenangi, terutama genangan air yang tercemar dengan limbah rumah tangga.Pemilihan tempat peletakan telur yang kemudian akan menetas menjadi jentik dilakukan oleh nyamuk betina dewasa. Setiap jenis nyamuk menyukai tempat berkembang biak, misal nyamuk Culex quinquefasciatus menyukai genangan air dengan polusi tinggi. Lama genangan air juga menentukan jenis-jenis jentik dan jumlah jentik yang ditemukan. Jentik-jentik nyamuk Mansonia dan Culex lebih menyukai genangan air yang sudah lama. ${ }^{12}$

Keberadaan ternak pada penelitian ini tidak terbukti sebagai faktor risiko filariasis hal ini ditunjukan dengan p-value $=0,110$. OR adjusted $=0,357$ dan 95\% CI $=$ 0,118 - 1,078. Hasil penelitian ini sejalan dengan penelitian yang dilakukan Febriyanto, dkk, 2008, bahwa keberadaan ternak tidak ada hubungannya dengan kejadian Filariasis dengan nilai $(\mathrm{OR}=0,49 ;$ p-value $=$ 0,67). Hal ini dibuktikan bahwa nyamuk Culex quinquefasciatus sebagai nyamuk vektor filariasis merupakan nyamuk anthropophilic. Sehingga walaupun banyak penduduk mempunyai hewan ternak akan tetapi kecenderungan untuk menggigit manusia lebih besar. Sehingga hewan ternak tidak bisa digunakan sebagai barrier terhadap gigitan nyamuk Culex quinquefasciatus.8

Keberadaan semak-semak pada penelitian ini tidak terbukti sebagai faktor risiko filariasis dengan $p$-value $=0,465$. OR=0,621 dan 95\% CI=0,237 - 1,626. Hasil penelitian ini sejalan dengan penelitian yang dilakukan oleh Febriyanto, dkk, 2008, yang mengatakan bahwa keberadaan semak-semak tidak mempunyai hubungan dengan kejadian filariasis dan hubungannya tidak bermakna $(\mathrm{OR}=0,59 ; p$-value $=0,61) .8$ Berdasarkan penelitian para ahli, keberadaan semak-semak terutama yang rimbun akan menghalangi sinar matahari ke permukaan tanah, sehingga adanya semak-semak yang rimbun berakibat lingkungan menjadi teduh serta lembab dan keadaan ini merupakan tempat istirahat yang disenangi nyamuk. ${ }^{13}$

Keberadaan tanaman air pada analisis bivariat pada penelitian ini tidak terbukti sebagai faktor risiko terjadinya filariasis dengan $p$-value $=0,427 . \mathrm{OR}=0,366$ dan $95 \% \mathrm{CI}=0,066-2,019$. Hasil penelitian ini sejalan dengan penelitian yang dilakukan oleh Marjuki (2006), bahwa keberadaan tanaman air tidak ada hubungannya dengan kejadian filariasis dengan nilai $(\mathrm{OR}=1,210$; $p$ value $=0,414) .{ }^{14}$ Tumbuhan air yang berjarak $100 \mathrm{~m}$ dari rumah juga bukan merupakan faktor risiko terjadinya filariasis. Tumbuhan air yang menjadi tempat perindukan bagi nyamuk vektor Mansonia terdapat di daerah yang berawa-rawa.1 Sedangkan Culex quinquefasciatus tempat perindukannya adalah air yang tercemar. Adapun tumbuhan air yang dijadikan sebagai inang Mansonia sp, antara lain eceng gondok, kayambang, dan lainnya. Keberadaan rawa-rawa pada penelitian ini tidak terbukti sebagai faktor risiko filariasis dengan $p$-value $=1,000$. $\mathrm{OR}=0,728$ dan $95 \% \mathrm{CI}=0,151-3,505$. Begitu juga keberadaan sawah pada penelitian ini tidak terbukti sebagai faktor risiko filariasis dengan nilai $p$ value $=0,261 . \mathrm{OR}=0,295$ dan $95 \% \mathrm{CI}=0,055-1,571$.

\section{SIMPULAN}

Penelitian ini menyimpulkan bahwa tinggal disekitar penderita filarisis kebiasaan berada diluar rumah pada malam hari, dan ketidakkepatuhan minum obat filariasis merupakan faktor risiko kejadian filariasis.

Oleh karena itu peneliti merekomendasikan upaya penyuluhan guna peningkatan pemahaman masyarakat agar minum obat secara tuntas. Selain itu diperlukan upaya untuk melakukan perlindungan diri bagi masyarakat yang biasa berada di luar rumah pada malam hari. Misalnya dengan menggunakan repelen atau memakai baju yang bisa menutup seluruh bagian tubuh. 


\section{DAFTAR PUSTAKA}

1 Direktorat Jenderal Pencegahan Penyakit \& Penyehatan Lingkungan, Direktorat P2B2 Subdit Filariasis \& Scistosomiasis, Pedoman Penatalaksanaan Kasus Klinis Penyakit Kaki Gajah (Filariasis). Jakarta : Depkes RI, 2006.

2. Dinas Kesehatan Kabupaten Pekalongan. Data Penelitian Filariasis Kabupaten Pekalongan tahun 2015.

3. Ansari R, Analisis Faktor Risiko Kejadian Filariasis di Dusun Tanjung Bayur Desa Sungai Asam Kecamatan Sungai Raya Kabupaten Pontianak Tahun 2004.

4. Dinas Kesehatan Kabupaten Pekalongan, Laporan Pencegahan Penyakit Menular Dinas Kesehatan Kabupaten Pekalongan, 2010.

5 Windiastuti I.A, Suhartono, Nurjazuli. Hubungan Kondisi Lingkungan Rumah, Sosial Ekonomi, dan Perilaku Masyarakat denganKejadian Filariasis di Kecamatan Pekalongan Selatan Kota Pekalongan. Jurnal Kesehatan Lingkungan IndonesiaVol. 12 No. 1 / April 2013, hal 51-57

6 Nurjazuli. Entomology Survey Based on Lymphatic Filariasis Locus in The District of Pekalongan City Indonesia. International Journal of Sciences: Basic and Applied Research2015, Vol 22 No. 1, p. 295-302

7. Syuhada Y. Studi Kondisi Lingkungan Rumah dan Perilaku Masyarakat Sebagai Faktor Risiko Kejadian
Filariasis di Kecamatan Buaran dan Tirto Kabupaten Pekalongan. Jurnal Kesling Indonesia, Semarang, 2012.

8. Febriyanto B, Maharani A, Widiarti.Faktor Risiko Filariasis di Desa Sambarejo Kecamatan Tirto Kabupaten Pekalongan Jawa Tengah, Balai Penelitian Vektor dan Reservoir Penyakit, Salatiga, 2008.

9. Soedarto, Penyakit-penyakit Infeksi di Indonesia. Jakarta: Widya Medika, 1990.

10. Suroso T. Prevention Control of Dengue and Dengue Haemorogic fever. Terjemahan dari WHO Regional Public SEARO, No. 29, Jakarta, 2000.

11.Reyke Uloli, Analisis Faktor-Faktor Risiko Kejadian Filariasis di Kabupaten Bonebolongo, Gorontalo. Tesis Universitas Gajah Mada, 2007.

12.Nasrin. Faktor-Faktor lingkungan dan perilaku yang berhubungan dengan kejadian Filari asis di Kabupaten Bangka Barat. Tesis Universitas Diponegoro, 2008.

13.Direktorat Jendral Pencegahan Penyakit \& Penyehatan Lingkungan. Ekologi \& Aspek Perilaku Vektor. Jakarta: Depkes RI, 2007.

14.Marjuki. Faktor Lingkungan dan Perilaku Yang Berpengaruh Terhadap Kejadian Filariasis Pada Daerah Endemis Filariasis Di Kecamatan Maro Sebo Kabupaten Muara Jambi Propinsi Jambi. Tesis Universitas Gajah Mada, 2008. 